\title{
Changes of the pro-hormone levels of vitamin D 25(OH)D in patients with newly diagnosed pulmonary tuberculosis treatment failure
}

\author{
R. M. Yasinskyi@*A,B,C,D, O. M. Raznatovska ${ }^{A, C, E, F}$
}

Zaporizhzhia State Medical University, Ukraine

A - research concept and design; B - collection and/or assembly of data; C - data analysis and interpretation; D - writing the article;

$\mathrm{E}$ - critical revision of the article; $\mathrm{F}$ - final approval of the article

Key words:

tuberculosis, treatment failure, vitamin D.

Pathologia 2020; 17 (1), 68-74

*E-mail: phthisiologist@ gmail.com
In Ukraine the number of patients with newly diagnosed tuberculosis (NDTB) who successfully complete the course of treatment reaches 60-65\% today. This is while the World Health Organization (WHO) criteria for successful treatment of this category of patients is $85 \%$. Scientists around the world are studying the possible pathogenetic factors of treatment failure of antimycobacterial therapy in patients with tuberculosis. Nowadays, the impact of vitamin D has been widely studied in this area. Studying of the dynamics of this indicator in patients with NDTB with widespread destructive tuberculosis in the lungs and bacterial excretion with the purpose of finding new markers of progression of a specific process and failure of treatment, as well as finding possible ways of additional pathogenetic therapy to accompany patients is actual. This approach will prevent treatment failure and, as a consequence, improve treatment efficiency.

Purpose. To determine changes in the pro-hormone levels of vitamin D 25(OH)D in patients with NDTB treatment failure during the intensive phase of antimycobacterial therapy.

Materials and methods. A prospective study involving 58 patients with NDTB lungs was performed. The patients were divided into 2 groups: 28 patients with pulmonary NDTB treatment failure were included in the $1^{\text {st }}$ group (the main group), 30 patients, who subsequently successfully completed the course of treatment were included in the $2^{\text {nd }}$ group (comparison group). The control group consisted of 29 healthy volunteer-donors. All the patients had been in inpatient treatment in Communal Institution "Zaporizhzhia Regional TB Clinical dispensary" during 2017-2019 years. Scientific medical-laboratory center of Zaporizhzhia State Medical University researched changes of the level of $25(\mathrm{OH}) \mathrm{D}$ in the blood serum by method of enzyme linked immunosorbent assay using immunoassay analyser Sirio $\mathrm{S}$ with "DIAsource ImmunoAssays S.A." kit (Belgium) (ng/ml). Blood sampling was made after an overnight fast. Blood was collected uniformly throughout the year in all patients and volunteers to avoid the effect of seasonal variability in vitamin $D$ in the blood.

Results. While healthy volunteers have a reduction in the level of pro-hormone $25(\mathrm{OH}) \mathrm{D}$ only in $51.7 \%$ of cases (deficiency in $13.8 \%$ and insufficiency in $37.9 \%$ ), patients with NDTB with generalized specific process in the lungs, the presence of destruction of over $3 \mathrm{~cm}$ in diameter and bacterial excretion at the beginning of intensive phase of antimycobacterial therapy ( 0 doses), have its decrease in $96.5 \%$ ( $81 \%$ deficiency and $15.5 \%$ insufficiency). $1 / 3$ of patients ( $35.7 \%$ at the $0^{\text {th }}$ dose and $32.1 \%$ at the $90^{\text {th }}$ dose) with tuberculosis treatment failure have pro-hormone levels $25(\mathrm{OH}) \mathrm{D}$ less than $7 \mathrm{ng} / \mathrm{ml}$, whereas in patients who successfully completed the course of treatment, this concentration of pro-hormone $25(\mathrm{OH}) \mathrm{D}$ was not even diagnosed. In the dynamics, after 3 months of intensive phase of antimycobacterial therapy (90 doses) in patients with NDTB treatment failure the levels of pro-hormone $25(\mathrm{OH}) \mathrm{D}$ continue to decrease significantly by 1.3 times relative to the initial values, which is 1.4 times lower than in patients who successfully completed the course of treatment.

Conclusions. In the vast majority of patients with NDTB of lungs with a risk of ineffective treatment, a pronounced deficiency of vitamin $D(1 / 3$ patients with pro-hormone levels $25(\mathrm{OH}) \mathrm{D}$ less than $7 \mathrm{ng} / \mathrm{ml})$ is determined at the beginning of treatment, and after 3 months of the intensive phase of antimycobacterial chemotherapy exacerbates vitamin $D$ deficiency. Therefore, this indicator can be used as a prognostic for the tuberculosis treatment failure and reducing the level of pro-hormone $25(\mathrm{OH})$ $\mathrm{D}$ in the dynamics require consideration of the problem of methods of its correction by the addition of vitamin $\mathrm{D}$.

\section{Ключові слова:} туберкульоз, невдача мікування, вітамін D.

Патологія. 2020.

T. 17, № 1(48),

C. $68-74$

\section{Зміни рівнів прогормона вітаміну D 25(ОН)D у хворих на неефективно мікований уперше діагностований туберкульоз легень}

\section{Р. М. Ясінський, О. М. Разнатовська}

В Україні частка хворих на вперше діагностований туберкульоз (ВДТБ), які успішно завершують курс лікування, становить 60-65 \%, а критерій Всесвітньої організації охорони здоров'я (ВООЗ) успішного лікування таких пацієнтів - 85 \%. Світова наукова спільнота вивчає можливі патогенетичні чинники невдачі антимікобактеріальної терапії у хворих на туберкульоз. У цьому аспекті нині широко вивчають вплив вітаміну D. Актуальним є вивчення динаміки цього показника у хворих на ВДТБ із поширеним деструктивним туберкульозним процесом у легенях і бактеріовиділення для пошуку нових маркерів прогресування специфічного процесу та невдачі лікування, а також для з'ясування можливих шляхів додаткової патогенетичної терапії супроводу хворих. Такий підхід дає можливість запобігти невдачі лікування та, як наслідок, сприятиме підвищенню ефективності лікування.

Мета роботи - визначити зміни рівнів прогормона вітаміну D 25(OH)D у хворих на неефективно лікований ВДТБ легень у процесі інтенсивної фази антимікобактеріальної терапії.

Матеріали та методи. Виконали проспективне дослідження, в яке залучили 58 хворих на ВДТБ легень. Пацієнтів поділили на 2 групи: у 1 (основну) включили 28 осіб із неефективно лікованим ВДТБ легень, у 2 групу (порівняння) - 30 
хворих, які згодом успішно завершили курс лікування. Контрольну групу утворили 29 здорових донорів-волонтерів. Усі пацієнти перебували на стаціонарному лікуванні в КУ «Запорізький обласний протитуберкульозний клінічний диспансер» у 2017-2019рp. Дослідження рівнів прогормона вітаміну D 25(OH)D здійснили в Навчальному медико-лабораторному центрі Запорізького державного медичного університету методом твердофазного імуноферментного аналізу, використовуючи імуноферментний рідер Sirio S і набори «DIAsource ImmunoAssays S.A.» (Бельгія), (нг/мл). Зразки крові пацієнтів брали вранці натще. У всіх хворих та у волонтерів кров брали рівномірно протягом року для уникнення впливу сезонної варіабельності вітаміну D у крові.

Результати. У здорових волонтерів зниження рівня прогормона 25(OH)D визначили тільки у 51,7 \% випадків (дефріцит - у 13,8 \%, недостатність - у 37,9 \%). У хворих на ВДТБ легень із поширеним специфрічним процесом у легенях, наявністю деструкцій понад 3 см у діаметрі та бактеріовиділенням на початку інтенсивної фрази антимікобактеріальної терапії (0 доз) зниження рівня прогормона 25(OH)D діагностували у 96,5 \% (у 81 \% - десріцит, у 15,5 \% - недостатність). $1 / 3$ хворих (35,7 \% на 0 дозі та 32,1 \% на 90 дозі) з неефективно лікованим туберкульозом мають рівні прогормона $25(\mathrm{OH}) \mathrm{D}$ менші ніж 7 нг/мл, а у хворих, які успішно завершили курс лікування, таку концентрацію прогормона 25(OH)D навіть не визначали. У динаміці, через 3 місяці інтенсивної фази антимікобактеріальної терапії (90 доз), у хворих на неефективно лікований ВДТБ легень рівні прогормона 25(OH)D вірогідно продовжують знижуватися в 1,3 раза щодо початкових значень; це в 1,4 раза менше ніж показники пацієнтів, які успішно завершили курс лікування.

Висновки. У більшості хворих на ВДТБ легень із ризиком неефективного лікування визначали виразний дефріцит вітаміну D (у 1/3 хворих рівні прогормона 25(OH)D менші ніж 7 нг/мл) на початку лікування, а через 3 місяці інтенсивної фази антимікобактеріальної хіміотерапії поглиблюється дефріцит вітаміну D. Отже, цей показник можна застосовувати як прогностичний щодо неефективного лікування туберкульозу, а зниження рівня прогормона 25(OH)D у динаміці потребує з'ясування доцільності методів його корекції шляхом додавання препаратів вітаміну D.

\section{Изменения уровней прогормона витамина D 25(OH)D у больных неэффективно леченным впервые диагностированным туберкулезом легких}

\section{Р. Н. Ясинский, Е. Н. Разнатовская}

В Украине доля больных с впервые диагностированным туберкулезом легких (ВДТБ), которые успешно заканчивают курс лечения, составляет 60-65 \%, а критерий Всемирной организации здравоохранения (ВО3) успешного лечения этой категории пациентов составляет 85 \%. Ученые всего мира изучают возможные патогенетические факторы неудачи антимикобактериальной терапии у больных туберкулезом. В этом аспекте широко изучают влияние витамина D. Актуально изучение динамики этого показателя у больных ВДТБ с распространенным деструктивным туберкулезным процессом в легких и бактериовыделением для поиска новых маркеров прогрессирования специфического процесса и неэффективного лечения, а также установления возможных путей дополнительной патогенетической терапии сопровождения больных. Такой подход позволит предупредить неудачу лечения и, как следствие, будет способствовать повышению эффективности лечения.

Цель работы - определить изменения уровней прогормона витамина D 25(OH)D у больных с неэффективно леченным ВДТБ легких в процессе интенсивной фазы антимикобактериальной терапии.

Материалы и методы. Выполнено проспективное исследование, в которое вошли 58 больных ВДТБ легких. Пациентов поделили на 2 группы: 1 (основная) - 28 пациентов с неэффективно леченным ВДТБ легких; 2 группа (сравнения) - 30 пациентов, которые потом успешно завершили курс лечения. Контрольную группу составили 29 здоровых доноров-волонтеров. Все пациенты находились на стационарном лечении в КУ «Запорожский областной противотуберкулезный клинический диспансер» в период 2017-2019 гг. Исследование уровней прогормона витамина D 25(OH)D выполнили в Учебном медико-лабораторном центре Запорожского государственного медицинского университета методом твердофразного иммуноферментного анализа с использованием иммуноферментного ридера Sirio S и наборов «DIAsource ImmunoAssays S.A.» (Бельгия), (нг/мл). Образцы крови пациентов брали утром натощак. У всех больных и у волонтеров кровь собирали равномерно в течение года для избегания влияния сезонной вариабельности витамина $D$ в крови.

Результаты. У здоровых волонтеров снижение уровня прогормона $25(\mathrm{OH}) \mathrm{D}$ установлено только в 51,7 \% случаев (десрицит - в 13,8 \%, недостаточность - в 37,9 \%). У больных ВДТБ с распространенным специфическим процессом в легких, с наличием деструкций более 3 см в диаметре и бактериовыделением в начале интенсивной фазы антимикобактериальной терапии (0 доз) снижение прогормона 25(ОН)D установлено у 96,5 \% (у 81 \% - десицит, у 15,5 \% недостаточность). 1/3 больных (35,7 \% на 0 дозе и 32,1 \% на 90 дозе) с неэффективно леченным туберкулезом имеют уровни прогормона 25(OH)D меньше 7 нг/мл. У больных, которые успешно завершили курс лечения, такая концентрация прогормона 25(OH)D даже не диагностирована. В динамике, через 3 месяца интенсивной фразы антимикобактериальной терапии (90 доз), у больных с неэфффективно леченным ВДТБ легких уровни прогормона 25(OH)D достоверно продолжают снижаться в 1,3 раза относительно начальных значений; это в 1,4 раза ниже относительно показателей пациентов, которые успешно завершили курс лечения.

Выводы. У большинства больных ВДТБ легких с риском неэффективного лечения установлен выраженный дефицит витамина D (у 1/3 пациентов уровни прогормона 25(OH)D меньше 7 нг/мл) в начале лечения, а через 3 месяца интенсивной фазы антимикобактериальной химиотерапии усугубляется дефицит витамина D. Таким обраом, этот показатель можно использовать как прогностический касательно неэффрективного лечения туберкулеза, а снижение уровня прогормона 25(OH)D в динамике обусловливает необходимость рассмотрения вопроса целесообразности методов его коррекции путем добавления препаратов витамина D.
Ключевые слова: туберкулез, неудача лечения, витамин D.

Патология. 2020.

T. 17, № 1(48).

C. $68-74$ 
Table 1. The study groups distribution by age and gender

\begin{tabular}{l|l|l|l} 
Indicator & $\begin{array}{l}\text { The } 1^{\text {st }} \text { group } \\
(\mathbf{n = 2 8})\end{array}$ & $\begin{array}{l}\text { The } \mathbf{2}^{\text {nd }} \text { group } \\
(\mathbf{n}=\mathbf{3 0})\end{array}$ & $\begin{array}{l}\text { The control group } \\
(\mathbf{n}=\mathbf{2 9})\end{array}$ \\
\hline Men & $20(71.4 \%)$ & $23(76.7 \%)$ & $19(65.6 \%)$ \\
Women & $8(28.6 \%)$ & $7(23.3 \%)$ & $11(34.4 \%)$ \\
Average age, years & $46.04 \pm 2.09$ & $43.0 \pm 3.48$ & $42.2 \pm 2.9$ \\
\hline
\end{tabular}

Newly diagnosed tuberculosis (NDTB) treatment failure is established in the patient according to the Ukrainian unified clinical guide of medical care (UUCGMC) "Tuberculosis" [1]. In Ukraine the number of patients with NDTB who successfully complete the course of treatment reaches $60-65 \%$ today [2]. This is while the World Health Organization (WHO) criteria for successful treatment of this category of patients is $85 \%$. The most important of causes of treatment failure are lack of adherence to treatment [2] and late detection of tuberculosis (when patients are diagnosed with massive bacterial excretion, a generalized process in the lungs and destructions) [3]. Ukrainian scientists mention [4] that changing the structure of clinical forms of tuberculosis toward widespread and acute-progressing forms will further reduce the effectiveness of treatment. At the same time, scientists around the world are studying the possible pathogenetic factors of treatment failure of antimycobacterial therapy (AMBT) in patients with tuberculosis. Nowadays, the impact of vitamin D has been widely studied in this area.

The following mechanisms of regulation of the immune response by vitamin $D$ in patients with tuberculosis have been established: activates macrophages, promotes the enhancement of antimycobacterial action of cathelicidin and $y$-interferon, activates oxidative stress [5]. It is believed that the gold standard for determining the content of this vitamin is the evaluating of the concentration of pro-hormone vitamin $D$ 25(OH)D [6].

Povorozniuk V. V et al. indicate that the vast majority of the population of Ukraine $(81.8 \%)$ has a deficiency of vitamin D and $4.6 \%$ inhabitants - insufficiency [6].

When comparing the levels of vitamin $\mathrm{D}$ pro-hormone in infected individuals and patients with active tuberculosis, the findings of the scientists have differences. Aibana O. et al. [5] and Gurjav U. et al. [7] on the basis of the obtained data argue that low levels of vitamin D in people with latent tuberculosis infection contribute to the development of active disease. Hong Y. et al. [8] note significantly lower levels of 25(OH)D in patients than in infected individuals. Ashenafi S. et al. [9] indicate that there is no difference between vitamin D pro-hormone levels between the compared contingents.

Wang Q. Z. et al. [10] indicate that patients with active tuberculosis with very low pro-hormone $25(\mathrm{OH}) \mathrm{D}$ levels (less than $8.5 \mathrm{ng} / \mathrm{ml}$ ) have more severe disease symptoms. Memon A. et al. [11] detect a deficiency of pro-hormone vitamin $D$ in the blood of patients with pulmonary tuberculosis with bacterial excretion and the presence of destructions.

In contrast to foreign authors, the role of vitamin $\mathrm{D}$ in the course of tuberculosis in children [12] and in adults with comorbid tuberculosis/chronic obstructive pulmonary disease [13] has been studied by Ukrainian scientists.
Both articles point to the important role of vitamin $D$ in pathogenesis of tuberculosis. However, there are no data available in domestic literature about the dynamics of vitamin $D$ levels in treatment failure newly diagnosed tuberculosis patients in dynamics.

Thus, due to the data on the predominantly low levels of vitamin $\mathrm{D}$ in Ukrainian population and the effect of pro-hormone $25(\mathrm{OH}) \mathrm{D}$ on the course of tuberculosis, studying of the dynamics of this indicator in patients with NDTB with widespread destructive tuberculosis in the lungs and bacterial excretion with the purpose of finding new markers of progression of a specific process and failure of treatment, as well as finding possible ways of additional pathogenetic therapy to accompany patients is actual. This approach will prevent treatment failure and, as a consequence, improve treatment efficiency.

\section{Aim}

To determine changes in the pro-hormone levels of vitamin $\mathrm{D} 25(\mathrm{OH}) \mathrm{D}$ in patients with NDTB treatment failure during the intensive phase of AMBT.

\section{Materials and methods}

A prospective study involving 58 patients with NDTB lungs was performed. The patients were divided into 2 groups: 28 patients with pulmonary NDTB treatment failure were included in the $1^{\text {st }}$ group (the main group), 30 patients, who subsequently successfully completed the course of treatment were included in the $2^{\text {nd }}$ group (comparison group). The control group consisted of 29 healthy volunteer-donors.

The age and gender of people in groups did not differ significantly (Table 1).

All the patients had been in inpatient treatment in Communal Institution "Zaporizhzhia Regional TB Clinical dispensary" during 2017-2019 years. Patients had been included in the study after signing the informed and voluntary consent. The study was approved by Commission for Bioethics of Zaporizhzhia State Medical University (Protocol № 1 of 02.02.2017).

Scientific medical-laboratory center of Zaporizhzhia State Medical University researched changes the level of $25(\mathrm{OH}) \mathrm{D}$ in the blood serum by method of enzyme linked immunosorbent assay using immunoassay analyser Sirio $S$ with "DIAsource ImmunoAssays S.A." kit (Belgium) (ng/ml). Blood sampling was made after an overnight fast. Blood was collected uniformly throughout the year in all patients and volunteers to avoid the effect of seasonal variability in vitamin $\mathrm{D}$ in the blood.

Entry criteria: newly diagnosed pulmonary tuberculosis, widespread pulmonary tuberculous process (infiltrative and disseminated), destructions in the pulmonary tissue over than $3 \mathrm{~cm}$ long and bacteriological proof.

Exclusionary criteria: other cases of the $2^{\text {nd }}$ categoria [1], chemoresistant tuberculosis, co-infection (TB/HIV), comorbidities, age over 70 years, non-compliance for treatment.

Since the widespread pulmonary tuberculous process was diagnosticated in the $1^{\text {st }}$ and $2^{\text {nd }}$ groups' patients, an intensive phase (IP) for patients was 90 
Table 2. Distribution of patients in groups depending on the concentration of pro-hormone $25(\mathrm{OH}) \mathrm{D}$ at its low values

\begin{tabular}{|c|c|c|c|c|c|c|c|c|}
\hline \multirow{2}{*}{$\begin{array}{l}\text { Concentration } \\
\text { of pro-hormone } 25(\mathrm{OH}) \mathrm{D}\end{array}$} & \multicolumn{4}{|c|}{ The $1^{\text {st }}$ group $(n=28)$} & \multicolumn{4}{|c|}{ The $2^{\text {nd }}$ group $(n=30)$} \\
\hline & $\begin{array}{l}0 \text { dos } \\
\text { abs. }\end{array}$ & $\%$ & \begin{tabular}{|l|}
$90 \mathrm{~d}$ \\
abs.
\end{tabular} & $\%$ & $\begin{array}{l}0 \text { dos } \\
\text { abs. }\end{array}$ & $\%$ & $\begin{array}{l}90 \mathrm{dc} \\
\text { abs. }\end{array}$ & $\%$ \\
\hline$<10 \mathrm{ng} / \mathrm{ml}$ & 11 & 39.3 & 11 & 39.3 & 8 & 26.7 & 8 & 26.7 \\
\hline$<9 \mathrm{ng} / \mathrm{ml}$ & 10 & 35.7 & 10 & 35.7 & 4 & 13.3 & 8 & 26.7 \\
\hline$<8 \mathrm{ng} / \mathrm{ml}$ & 10 & 35.7 & 10 & 35.7 & 4 & 13.3 & 6 & 20 \\
\hline$<7 \mathrm{ng} / \mathrm{ml}$ & 10 & $35.7^{\circ}$ & 9 & $32.1^{\#}$ & 0 & 0 & 0 & 0 \\
\hline
\end{tabular}

*: a significant difference between indicators of groups at the 0 doses, $P<0.05$; \#: a significant difference between indicators of groups at the 90 doses, $P<0.05$.

doses. Therefore, treatment efficacy was evaluated in 3 months according to the Unified medical care protocol "Tuberculosis" [1].

Pro-hormone vitamin D 25(OH)D level was conducted at the beginning of IP of the treatment ( 0 doses) and at the end of IP (after 3 months of the treatment -90 doses).

Statistica for Windows 13.0 (Copyright 1984-2018 TIBCO Software Inc. All rights reserved. Licence № JPZ8041382130ARCN10-J) software was used for the statistical analysis. Normality of distribution of the quantitative indicators was performed by ShapiroWilk test. Research evidence are submitted in a form $M \pm M$, where $M$ stands for average mean, $m$ stands for mean error. The statistical significance of differences between groups was determined using Student's T-test (since the normality of distribution of the quantitative indicators was performed). The significance of the difference in the distribution of indicators (the distribution of patients in study groups in dynamics of treatment depending on the status of pro-hormone $25(\mathrm{OH}) \mathrm{D}$ ) between groups was determined by comparison of frequencies. To compare qualitative indicators (distribution of patients in groups depending on the concentration of pro-hormone $25(\mathrm{OH}) \mathrm{D}$ at its low values) used the method of $X$-squares with Yates correction. The results considered to be significant only if the $P$-value was lower than 0.05 .

\section{Results}

Given that the concentration of pro-hormone $25(\mathrm{OH}) \mathrm{D}$ less than $20 \mathrm{ng} / \mathrm{ml}$ is a deficiency of vitamin $D$, and the concentration of $21-29 \mathrm{ng} / \mathrm{ml}$ is its insufficiency [5], the distribution of patients in the study groups during treatment depending on the status of pro-hormone $25(\mathrm{OH}) \mathrm{D}$ was done (Fig. 1).

As we can see, healthy volunteers had pro-hormone $25(\mathrm{OH}) \mathrm{D}$ deficiency only in 4 people $(13.8 \%)$ and its insufficiency in 11 (37.9\%). This indicator was normal in almost half of the people - 17 (48.3\%). Analyzing the data of patients, it was found that the frequency of both pro-hormone $25(\mathrm{OH}) \mathrm{D}$ deficiency and its insufficiency was almost the same and did not differ significantly in patients of both groups 1 and 2 at the beginning of IP of AMBT ( 0 doses). Thus, in the vast majority of the $1^{\text {st }}$ and $2^{\text {nd }}$ groups' patients there was a pro-hormone $25(\mathrm{OH}) \mathrm{D}$ deficiency (in 22 (78.6\%) and 25 (89.3\%) patients, respectively), which is significantly more frequent than in healthy volunteers: by 5.6 times $(P<0.01)$ in the $1^{\text {st }}$ group and by 5.3 times $(P<0.01)$ in the $2^{\text {nd }}$ group. However, the frequency of pro-hormone $25(\mathrm{OH}) \mathrm{D}$ insufficiency in patients of the $1^{\text {st }}$ and $2^{\text {nd }}$ groups was lower but not significantly than in healthy volunteers: by 2.6 times in the $1^{\text {st }}$ group and by 2.2 times in the $2^{\text {nd }}$ group (in $4(14.3 \%)$ in the $1^{\text {st }}$ group and in $5(16.7 \%)$ in the $2^{\text {nd }}$ group versus $11(37.9 \%)$ in control group, $\mathrm{P}>0.05$ ).

At the end of IP of AMBT (90 doses) there were no patients with vitamin $D$ insufficiency in the $1^{\text {st }}$ group who had treatment failure $(P<0.05$ compared to control group), on the other hand, the frequency of its deficiency increased by 10.7 (25 (89.3\% compared to 22 (78.3\%); $\mathrm{P}>0.05)$ and this index normalized by $3.6 \%(3(10.7 \%)$ against 2 (7.1\%); P > 0.05).

In patients who successfully completed IP of AMBT (90 doses) the frequency of persons with normal level of pro-hormone $25(\mathrm{OH}) \mathrm{D}$ was decreased by $3.3 \%$ (2 patients $(6.7 \%)$ versus $3(10 \%) ; P>0.05)$ and frequency of sick people with its insufficiency was reduced by $3.4 \%$ (4 (13.3\%) against 5 (16.7\%); P > 0.05), instead the frequency of its deficit increased by $6.7 \%$ (24 patients $(80 \%)$ at the beginning against $22(73.3 \%)$ at the end of IP; $\mathrm{P}>0.05$ ).

Based on the data of previous studies [10], that in patients with active tuberculosis with very low values of pro-hormone $25(\mathrm{OH}) \mathrm{D}$ (less than $8.5 \mathrm{ng} / \mathrm{ml}$ ) more severe symptoms occur, the distribution of patients in groups depending on the concentration of pro-hormone $25(\mathrm{OH}) \mathrm{D}$ at its low values was done (Table 2). The proportion of patients with an appropriate concentration $10 \mathrm{ng} / \mathrm{ml}$ and below was evaluated. The concentration of pro-hormone 25(OH)D $10 \mathrm{ng} / \mathrm{ml}$ and below was not diagnosed in healthy volunteers.

It was found that the number of patients in group 1 with $25(\mathrm{OH}) \mathrm{D}$ level less than $7 \mathrm{ng} / \mathrm{ml}$ at the beginning of treatment and after 3 months reached more than $1 / 3$ of patients ( $35.7 \%$ and $32.1 \%$ respectively), which is reliable distinguished patients from those who successfully completed the course of treatment (group 2), where such a concentration of pro-hormone $25(\mathrm{OH}) \mathrm{D}(<7 \mathrm{ng} / \mathrm{ml})$ was not even diagnosed.

Comparing the levels of pro-hormone $25(\mathrm{OH}) \mathrm{D}$ in patients at the beginning of treatment ( 0 doses), it was found that they were reduced by 2.1 times in group 1 and by 1.7 times - in group 2 of patients relative to the corresponding indicator in the control $(14.5 \pm 2.55 \mathrm{ng} / \mathrm{ml}$ and $18.28 \pm 2.77$ $\mathrm{ng} / \mathrm{ml}$ versus $31.04 \pm 2.73 \mathrm{ng} / \mathrm{ml}$; $\mathrm{P}<0.01$ ), (Fig. 2).

The dynamics showed a decrease in the levels of pro-hormone $25(\mathrm{OH}) \mathrm{D}$ in both groups, but a significant decrease by 1.3 times occurred in patients of 1 group $(14.5 \pm 2.55 \mathrm{ng} / \mathrm{ml}$ versus $10.9 \pm 1.18 \mathrm{ng} / \mathrm{ml} ; P<0.05$ and $18.28 \pm 2.77 \mathrm{ng} / \mathrm{ml}$ versus $15.48 \pm 2.3 \mathrm{ng} / \mathrm{ml} ; \mathrm{P}>0.05)$.

After 3 months of treatment ( 90 doses), the levels of pro-hormone $25(\mathrm{OH}) \mathrm{D}$ remained lower in both groups 


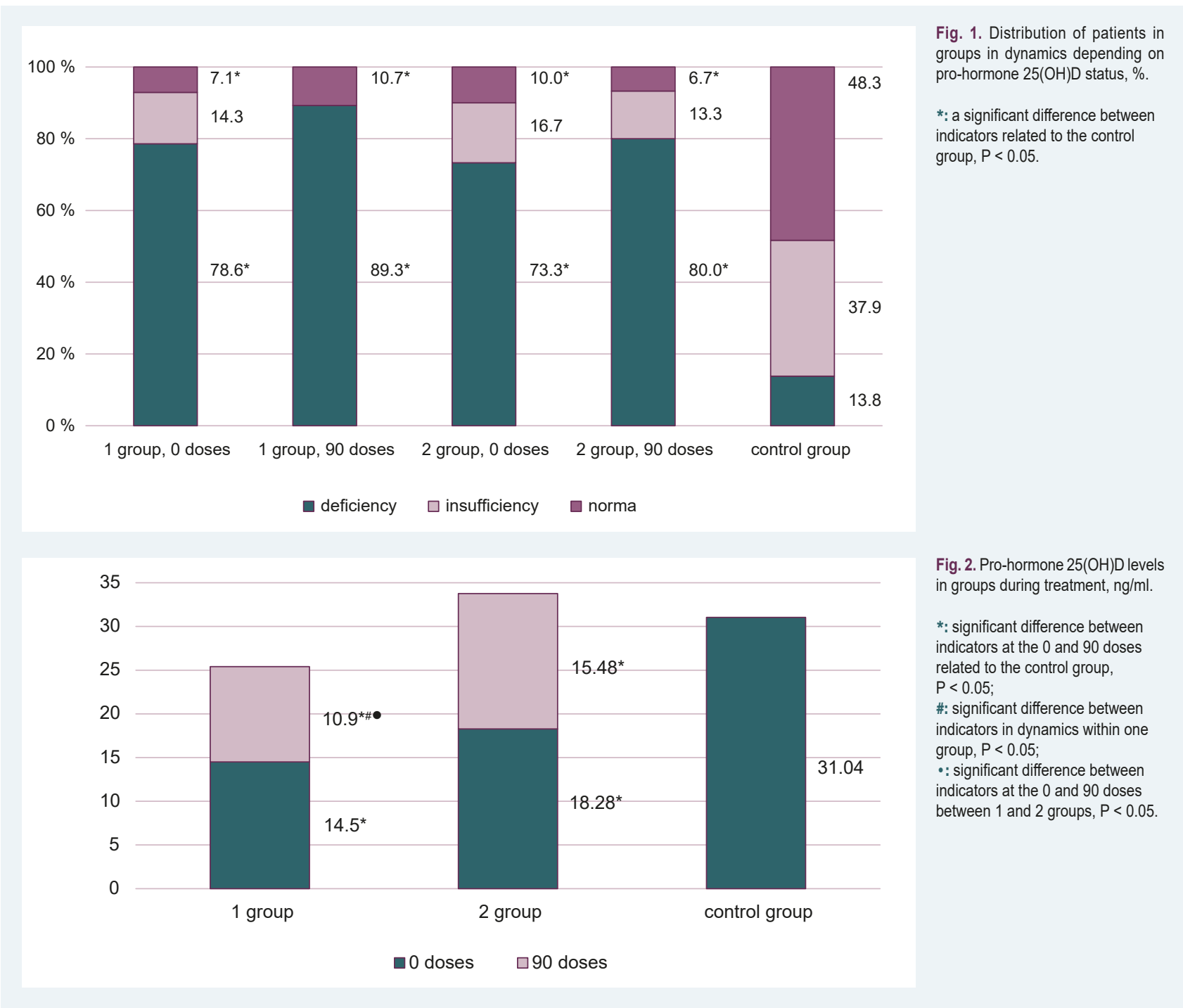

compared to controls: by 2.8 times for 1 group and by 2 times for 2 group $(10.9 \pm 1.18 \mathrm{ng} / \mathrm{ml}$ and $15.48 \pm 2.3 \mathrm{ng} / \mathrm{ml}$ against $31.04 \pm 2.73 \mathrm{ng} / \mathrm{ml} ; \mathrm{P}<0.001)$.

Comparing the levels of pro-hormone $25(\mathrm{OH}) \mathrm{D}$ after 3 months of treatment ( 90 doses) between 1 and 2 groups, it was found that in 1 group it was by 1.4 times lower: $10.9 \pm 1.18 \mathrm{ng} / \mathrm{ml}$ against $15.48 \pm 2.3 \mathrm{ng} / \mathrm{ml}$; $P<0.05$.

\section{Discussion}

It was found that there are $56(96.5 \%)$ patients with low levels of pro-hormone $25(\mathrm{OH}) \mathrm{D}$, of which 47 people $(81 \%)$ have a deficiency and $9(15.5 \%)$ have a insufficiency among 58 patients with NDTB of lungs with generalized pulmonary involvement, destruction of lung tissue over $3 \mathrm{~cm}$ in diameter and with bacteriological proof (which is a risk of treatment failure) at the beginning of IP of AMBT (0 doses). These results confirmed the findings of previous studies [11], but Memon A. et al. determined this indicator in patients with NDTB with bacterial excretion and the presence of destruction, regardless of the size of affected lungs' areas. At the same time, we found that more than $1 / 3$ of patients who will have treatment failure have levels of $25(\mathrm{OH}) \mathrm{D}$ below $7 \mathrm{ng} / \mathrm{ml}$.

A further significant decrease in the level of pro-hormone $25(\mathrm{OH}) \mathrm{D}$ by 1.3 times in patients with treatment failure and a its decrease (but not significant) in patients who successfully completed the course of treatment in dynamics in patients with NDTB of lungs was determined. Tukvadze N. et al. [14] found that the levels of pro-hormone $25(\mathrm{OH}) \mathrm{D}$ did not change during treatment in patients receiving AMBT (both at the $60^{\text {th }}$ and $90^{\text {th }}$ doses), but the researchers examined patients with bacterial excretion, which in $78.8 \%$ of cases had no destruction in the lungs. Mily A. et al. [15] also did not detect changes in vitamin D pro-hormone levels after IP of AMBT completion (90 doses). The opposite results were obtained by Sloan D. J. et al. [16] and Tostmann A. et al. [17], who received data that after 2 months of IP of AMBT ( 60 doses) vitamin $\mathrm{D}$ levels increased in patients. The authors attribute this to the fact that in the course of treatment in patients improves nutrition and general clinical condition, which contributes to an increase in time spent on the street and, as a consequence, increases the supply of vitamin $D$ to the body.

Hazan Z. et al. [18] obtained results similar to ours, they found that pro-hormone $25(\mathrm{OH}) \mathrm{D}$ levels in patients 
with bacterial excretion were significantly reduced within 3 months in patients who had deficiency, insufficiency, and normal values. The authors explained this effect by antimycobacterial drugs of the first line (isoniazid, rifampicin, pyrazinamide, ethambutol) impact on the metabolism of vitamin D. However, data on this effect on vitamin $\mathrm{D}$ metabolism are controversial. Thus, some researchers have found that isoniazid and rifampicin promote the increase in serum levels of pro-hormone 25(OH)D [19]. Others have found that first-line drugs so affect the metabolism of vitamin $D$, which reduce the vitamin D-induced production of cathelicidin by macrophages [20].

Considering the fact that the pro-hormone $25(\mathrm{OH}) \mathrm{D}$ levels after 3 months of IP of AMBT ( 90 doses) in patients who failed treatment were 1.4 times lower than in patients who successfully completed the course of treatment. This is despite the fact that all patients received the same standardized AMBT. Therefore, it is likely that not only drugs have an effect on vitamin $D$ metabolism. We believe that due to the generalized tuberculosis and presence of the destruction over $3 \mathrm{~cm}$ and bacterial excretion, vitamin $D$ is actively involved in the protection against tuberculosis and therefore the concentration of pro-hormone $25(\mathrm{OH}) \mathrm{D}$ in the serum is reduced, especially if immune answer is insufficient to stabilize the process after 3 months of treatment with antimycobacterial drugs and treatment failure is diagnosed.

\section{Conclusions}

1. While healthy volunteers have a reduction in the level of pro-hormone $25(\mathrm{OH}) \mathrm{D}$ only in $51.7 \%$ of cases (deficiency in $13.8 \%$ and insufficiency in $37.9 \%$ ), patients with NDTB with generalized specific process in the lungs, the presence of destruction of over $3 \mathrm{~cm}$ in diameter and bacterial excretion at the beginning of IP of AMBT (0 doses), have its decrease in $96.5 \%$ (81\% deficiency and $15.5 \%$ insufficiency).

2. $1 / 3$ of patients $\left(35.7 \%\right.$ at the $0^{\text {th }}$ dose and $32.1 \%$ at the $90^{\text {th }}$ dose) with tuberculosis treatment failure have pro-hormone levels $25(\mathrm{OH}) \mathrm{D}$ less than $7 \mathrm{ng} / \mathrm{ml}$, whereas in patients who successfully completed the course of treatment, this concentration of pro-hormone $25(\mathrm{OH}) \mathrm{D}$ was not even diagnosed.

3. In the dynamics, after 3 months of IP of AMBT ( 90 doses) in patients with NDTB treatment failure the levels of pro-hormone $25(\mathrm{OH}) \mathrm{D}$ continue to decrease significantly by 1.3 times relative to the initial values, which is 1.4 times lower than in patients who successfully completed the course of treatment.

Thus, in the vast majority of patients with NDTB of lungs with a risk of ineffective treatment, a pronounced deficiency of vitamin $D(1 / 3$ patients with pro-hormone levels $25(\mathrm{OH}) \mathrm{D}$ less than $7 \mathrm{ng} / \mathrm{ml}$ ) is determined at the beginning of treatment, and after 3 months of the intensive phase of antimycobacterial chemotherapy exacerbates vitamin $\mathrm{D}$ deficiency. Therefore, this indicator can be used as a prognostic for the tuberculosis treatment failure and reducing the level of pro-hormone $25(\mathrm{OH}) \mathrm{D}$ in the dynamics require consideration of the problem of methods of its correction by the addition of vitamin $\mathrm{D}$.
Prospects for further scientific research. To develop an algorithm for managing this category of patients in order to reduce the number of treatment failures and increase the effectiveness of antimycobacterial therapy.

Conflicts of interest: authors have no conflict of interest to declare. Конфлікт інтересів: віАсутній.

Надійшла Ао редакції / Received: 25.11.2019

Після Аоопрацювання / Revised: 10.12.2019

Прийнято Ао Аруку / Accepted: 11.12.2019

Information about authors:

Yasinskyi R. M., MD, PhD, Associate Professor of the Department of Phthisiology and Pulmonology, Zaporizhzhia State Medical University, Ukraine.

ORCID ID: 0000-0003-4132-731X

Raznatovska O. M., MD, PhD, DSc, Professor, Head of the Department of Phthisiology and Pulmonology, Zaporizhzhia

State Medical University, Ukraine.

ORCID ID: 0000-0003-2252-9063

Відомості про авторів:

Ясінський Р. М., канА. МеА. наук., Аоцент каф. фтизіатрії і пульмонології, Запорізький Аержавний медичний університет, україна.

Разнатовська О. М., А-р меА. наук, професор, зав. каф. фтизіатріі і пульмонології, Запорізький Аержавний меАичний університет, Україна.

Сведения об авторах:

Ясинский Р. Н., канА. меА. наук, Аоцент каф. фтизиатрии и пульмонологии, Запорожский госуАарственный меАицинский университет, Украина.

Разнатовская Е. Н., А-р меА. наук, профессор,

зав. каф. фтизиатрии и пульмонологии, Запорожский государственный медицинский университет, Украина.

\section{References}

[1] Ministry of Health of Ukraine. (2014, September 4). Unifikovanyi klinichnyi protocol pervynnoi, vtorynnoi (spetsializovanoi) ta tretynnoi (vysokospetsializovanoi) medychnoi dopomohy. Tuberkuloz. Nakaz MOZ 04.09.2014 No. 620 [Unified clinical protocol for primary, secondary (specialized) and tertiary (highly specialized) medical care for adults. Tuberculosis (No. 620)]. https://zakon.rada.gov.ua/rada/file/ text/27/f434621n28.pdf

[2] Feshenko, Yu. I. (2019). Suchasni tendentsii vyvchennia problem tuberkulozu [Current trends in the study of tuberculosis problems]. Ukrainskyi pulmonolohichnyi zhurnal - Ukrainian Pulmonary Journal, (1), 8-24 [in Ukrainian]. https://doi.org/10.312.15/2306-4927-2019103-1-8-24

[3] Melnyk, V. M., Novozhylova, I. O., \& Matusevych, V. H. (2019). Problema nyzkoi efektyvnosti likuvannia khvorykh na tuberkuloz lehen [The problem of low efficiency of treatment of patients with pulmonary tuberculosis]. Ukrainskyi pulmonolohichnyi zhurnal - Ukrainian Pulmonary Journal, (1), 25-32 [in Ukrainian]. https://doi.org/10.312.15/23064927-2019-103-1-25-32

[4] Feshchenko, Yu. I., Todoriko, L. D., Kuzhko, M. M., \& Humeniuk, M. I. (2018). Patomorfoz tuberkulozu - realii sohodennia, khimiorezystentnist, yak oznaka prohresuvannia [Tuberculosis pathomorphosis the realities of today, chemoresistance as a sign of progression]. Ukrainskyi pulmonolohichnyi zhurnal - Ukrainian Pulmonary Journal, (2), 6-10 [in Ukrainian]. https://doi.org/10.31215/2306-4927-2018100-2-6-10

[5] Aibana, O., Huang, C. C., Aboud, S., Arnedo-Pena, A., Becerra, M. C. Bellido-Blasco, J., ... Murray, M. B. (2019). Vitamin D status and risk of incident tuberculosis disease: A nested case-control study, systematic review, and individual-participant data meta-analysis. Plos Medicine, 16(9), Article e1002907. https://doi.org/10.1371/journal.pmed.1002907

[6] Povorozniuk, V. V., Balatska, N. I., Muts, V. Ya., \& Vdovina, O. A. (2011). Defitsyt ta nedostatnist vitaminu D u zhyteliv Ukrainy [Vitamin D deficiency and insufficiency in the population of Ukraine]. Bol. Sustavy. Pozvonochnik - Pain. Joints. Spine, (4), 5-13 [in Ukrainian]. 
[7] Gurjav, U., Ankhbat, M., Ganbaatar, G., Batjarga, K., Ochirbat, B., Baigal, D., Jargalsaikhan, B., Munkhjargal, O., Bolormaa, S., Yansanjav, N., Luvsanyandan, N., Dorj, G., Dambaa, N., Bromage, S., \& Ganmaa, D. (2019). Vitamin D deficiency is associated with tuberculosis infection among household contacts in Ulaanbaatar, Mongolia. International Journal of Tuberculosis and Lung Disease, 23(8), 919-923. https://doi.org/10.5588/ijtld.19.0047

[8] Hong, Y., Kim, Y., Lee, J. J., Lee, M. G., Lee, C. Y., Heo, J., Han, S. S., Lee, S. J., Kim, W. J., \& Hong, J. Y. (2019). Levels of vitamin D-associated cytokines distinguish between active and latent tuberculosis following a tuberculosis outbreak. Bmc Infectious Diseases, 19, Article 151. https://doi.org/10.1186/s12879-019-3798-5

[9] Ashenafi, S., Mazurek, J., Rehn, A., Lemma, B., Aderaye, G., Bekele,A. Assefa, G., Chanyalew, M., Aseffa, A., Andersson, J., Bergman, P., \& Brighenti, S. (2018). Vitamin D-3 Status and the Association with Human Cathelicidin Expression in Patients with Different Clinical Forms of Active Tuberculosis. Nutrients, 10(6), Article 721. https://doi. org/10.3390/nu10060721

[10] Wang, Q. Z., Liu, Y. F., Ma, Y., Han, L., Dou, M., Zou, Y., Sun, L. M., Tian, H., Li, T. X., Jiang, G. F., Du, B. L., Kou, T. Y., Song, J. Q., Kok, F. J., \& Schouten, E. G. (2018). Severe hypovitaminosis D in active tuberculosis patients and its predictors. Clinical Nutrition, 37(3), 1034-1040. https://doi.org/10.1016/j.clnu.2017.04.018

[11] Memon, A., Raqeeb, A., Humaira, M., \& Khoharo, H. K. (2016). Vitamin D-3 in Newly Diagnosed Pulmonary Tuberculosis Patients: A Comparative Case Control Study. Journal of the Liaquat University of Medical and Health Sciences, 15(1), 16-20.

[12] Mykolyshyn, L. I., Piskur, Z. I., Didyk, Y. Y., \& Sikirynska, O. S. (2016). Klinichni parametry vitaminu $\mathrm{D}$ pry tuberkulozi u ditei [Clinical parameters of vitamin $\mathrm{D}$ in tuberculosis in children]. Tuberkuloz, lehenevi khvoroby, VIL infektsiia, (4), 32-38. [in Ukrainian].

[13] Cherenko, S. O. (2012). Tuberkuloz i khronichne obstruktyvne zakhvoriuvannia lehen - spilni mekhanizmy patohenezu ta vplyv vitaminu D na yikh perebih [Tuberculosis and chronic obstructive pulmonary disease - common mechanisms of pathogenesis and the impact of vitamin D on their course]. Ukrainskyi khimioterapevtychnyi zhurnal, (1-2), 91-97. [in Ukrainian].

[14] Tukvadze, N., Sanikidze, E., Kipiani, M., Hebbar, G., Easley, K. A. Shenvi, N., Kempker, R. R., Frediani, J. K., Mirtskhulava, V., Alvarez, J. A., Lomtadze, N., Vashakidze, L., Hao, L., Del Rio, C., Tangpricha, V., Blumberg, H. M., \& Ziegler, T. R. (2015). High-dose vitamin D-3 in adults with pulmonary tuberculosis: a double-blind randomized controlled trial. American Journal of Clinical Nutrition, 102(5), 10591069. https://doi.org/10.3945/ajcn.115.113886

[15] Mily, A., Rekha, R. S., Kamal, S. M. M., Arifuzzaman, A. M., Rahim, Z., Khan, L., Haq, M. A., Zaman, K., Bergman, P., Brighenti, S., Gudmundsson, G. H., Agerberth, B., \& Raqib, R. (2015). Significant Effects of Oral Phenylbutyrate and Vitamin D3 Adjunctive Therapy in Pulmonary Tuberculosis: A Randomized Controlled Trial. Plos One, 10(9), Article e0138340. https://doi.org/10.1371/journal.pone. 0138340

[16] Sloan, D. J., Mwandumba, H. C., Kamdolozi, M., Shani, D., Chisale, B. Dutton, J., Khoo, S. H., Allain, T. J., \& Davies, G. R. (2015). Vitamin D deficiency in Malawian adults with pulmonary tuberculosis: risk factors and treatment outcomes. International Journal of Tuberculosis and Lung Disease, 19(8), 904-911. https://doi.org/10.5588/ijtld.15.0071

[17] Tostmann, A., Wielders, J. P., Kibiki, G. S., Verhoef, H., Boeree, M. J., \& van der Ven A. J. (2010). Serum 25-hydroxy-vitamin D3 concentrations increase during tuberculosis treatment in Tanzania. International Union against Tuberculosis and Lung Disease, 14(9), 1147-1152.

[18] Hasan, Z., Salahuddin, N., Rao, N., Aqeel, M., Mahmood, F., Ali, F., Ashraf, M., Rahman, F., Mahmood, S., Islam, M., Dildar, B., Anwer, T., Oiighor, F., Sharif, N., \& Ullah, A. R. (2014). Change in serum CXCL10 levels during anti-tuberculosis treatment depends on vitamin $D$ status. International Journal of Tuberculosis and Lung Disease, 18(4), 466-469. https://doi.org/10.5588/ijtld.13.0460

[19] Sheng, L., Xue, Y., He, X., Zhu, Y. G., Li, H. D., Wu, Y. Q., Dang, R. L., Tang, M. M., \& Jiang, P. (2015). Effects of repeated administration of rifampicin and isoniazid on vitamin D metabolism in mice. Steroids, 104, 203-207. https://doi.org/10.1016/j.steroids.2015.10.004

[20] Chesdachai, S., Zughaier, S. M., Hao, L., Kempker, R. R., Blumberg, H. M., Ziegler, T. R., \& Tangpricha, V. (2016). The effects of first-line anti-tuberculosis drugs on the actions of vitamin $D$ in human macrophages. Journal of Clinical and Translational Endocrinology, 6 , 23-29. https://doi.org/10.1016/j.jcte.2016.08.005 